\title{
ACE-inhibitory peptides from bovine caseins released with peptidases from Maclura pomifera latex
}

\author{
María Alicia Corrons ${ }^{\mathrm{a}}$, Constanza Silvina Liggieri ${ }^{\mathrm{a}}$, Sebastián Alejandro Trejo ${ }^{\mathrm{b}}$, Mariela Anahí Bruno ${ }^{\mathrm{a}, *}$ \\ a CIProVe, Faculty of Exact Sciences, National University of La Plata (UNLP), la Plata, Argentina \\ ${ }^{\mathrm{b}}$ Multidisciplinary Institute of Cellular Biology (IMBICE, CONICET-UNLP), La Plata, Argentina
}

\section{A R T I C L E I N F O}

\section{Article history:}

Received 5 October 2016

Received in revised form 4 January 2017

Accepted 6 January 2017

Available online 07 January 2017

\section{Keywords:}

Maclura pomifera

Plant peptidase

Hydrolysate

ACE-inhibitory peptide

\begin{abstract}
A B S T R A C T
In work reported here, a proteolytic extract prepared from Maclura pomifera latex was employed to hydrolyze bovine caseins. Densitograms of Tricine-sodium-dodecyl-sulfate-polyacrylamide-gel electrophoresis (SDSPAGE) indicated that the caseins were considerably degraded after a 10-min reaction. The degree of hydrolysis determined by the 2,4,6-trinitrobenzenesulfonic-acid method was $17.1 \pm 0.7 \%$ after $180 \mathrm{~min}$ of digestion. The concentration of small peptides increased with hydrolysis time, and analysis by reverse-phase highperformance liquid chromatography (RP HPLC) and mass spectrometry, revealed a virtually unchanged peptide profile. These results suggested that those proteases were highly specific, as only certain peptide bonds were cleaved. The hydrolysate of 180 min displayed the highest inhibition of angiotensin-converting enzyme (ACE) showing an $\mathrm{IC}_{50}$ of $1.72 \pm 0.25 \mathrm{mg} / \mathrm{mL}$, and the analysis of the peptide fractionation in this hydrolysate by RP HPLC exhibited two peaks responsible for that activity. Fragmentation analysis through the use of iterated matrix-assisted-laser-desorption-ionization-time-of-flight mass spectrometry (MALDI-TOF/TOF MS/MS) with the aid of bioinformatics tools enabled us to deduce two peptide sequences-one, YQEPVLGPVRGPFPIV, having been previously reported as an ACE-inhibitor; the other, RFFVAPFPE, as yet undescribed. The presence of bioactive peptides in these casein hydrolysates argues for their potential use in the development of functional foods.
\end{abstract}

(c) 2017 Elsevier Ltd. All rights reserved.

\section{Introduction}

Milk is a complex fluid containing literally hundreds of molecular species and providing energy (supplied by lipids and lactose), essential and nonessential amino acids (supplied by proteins), essential fatty acids, vitamins, inorganic elements, and water (O'Mahony \& Fox, 2014). Cow milk possesses a protein concentration of approximately $32-38 \mathrm{~g} / \mathrm{L}$. This high-quality protein consists of about $20 \%$ whey proteins, whose major components are $\alpha$-lactalbumin and $\beta$ lactoglobulin, and $80 \%$ caseins, divided into four major fractions, $\alpha \mathrm{S} 1-$, $\alpha \mathrm{S} 2-, \beta-$, and $\kappa$-casein, which are arranged in micelles (Gellrich, Meyer, \& Wiedemann, 2014).

Among the different dairy products available on the market nowadays, protein hydrolysates constitute one of the most significant since they are obtained with the purpose of meeting special dietary needs (Clemente, 2000; Soares et al., 2006), increasing digestibility (Koopman et al., 2009), reducing allergenicity (Bu, Luo, Chen, Liu, \&

\footnotetext{
* Corresponding author at: CIProVe, Faculty of Exact Sciences, National University of La Plata, 47 \& 115, 1900 La Plata, Argentina.

E-mail addresses: mariaaliciacorrons@hotmail.com (M.A. Corrons), cliggieri@biol.unlp.edu.ar (C.S. Liggieri), sebatrejo@gmail.com (S.A. Trejo), brunomariela@biol.unlp.edu.ar (M.A. Bruno).
}

Zhu, 2013), or containing small peptides with biologic actions (Korhonen, 2009). To achieve those ends, proteolytic enzymes coming from various animal, plant, or microbial sources are used to digest food proteins (Aleixandre, Miguel, \& Muguerza, 2008; Silva, Pihlanto, \& Malcata, 2006).

A hydrolysate containing bioactive peptides can be considered as a functional food since it provides health benefits beyond basic nutrition and, being similar in appearance to conventional food, is therefore suitable for consumption as part of a normal diet (Siro, Kapolna, Kapolna, \& Lugasi, 2008). Bioactive peptides are specific protein fragments that have a positive impact on the functioning or conditions of living beings, thereby improving their health (Pérez Espitia et al., 2012). The size of these peptides can vary from two to twenty amino-acid residues, and their specific activity is based on their sequence and-amino acid composition. Milk proteins are considered one of the richest sources of these compounds (Korhonen \& Pihlanto, 2006). Bioactive peptides from bovine caseins comprise-among other species-the caseinophosphopeptides, involved in the transport and absorption of certain minerals; isracidin, an immunomodulator; the casomorphins and casoxins, respective opioid-receptor agonists and antagonists; and the casokinins, antihypertensive agents (Phelan, Aherne, FitzGerald, \& O'Brien, 2009). The last of these inhibits the ACE that plays a central role in blood-pressure regulation through the renin-angiotensin-aldosterone system. Some of the 
bovine casokinins correspond to peptides f23-24, f23-27, and f194-199 from $\alpha_{\mathrm{S} 1}$-casein, as well as to f177-183, and f193-202 from $\beta$-casein, among others (Silva \& Malcata, 2005). Casokinins such as Ile-Pro-Pro and Val-Pro-Pro from $\beta$-casein are present in commercial dairy products with antihypertensive properties such as "Calpis" (Sour milk) from Calpis Co., Japan, and Evolus (a calcium-enriched fermented milk drink) produced by Valio Oy, Finland (Korhonen, 2009).

The Osage orange Maclura pomifera (Raf.) Schneid (Moraceae) is an ornamental species cultivated in Argentina, whose fruit latex contains unusual quantities of serine peptidases that have been used to hydrolyze soy and whey proteins (Bertucci, Liggieri, Colombo, Vairo Cavalli, \& Bruno, 2015; Ortiz \& Añón, 2001) and to clot bovine milk (Corrons, Bertucci, Liggieri, López, \& Bruno, 2012). The aim of the present work was to prepare and characterize bovine casein hydrolysates through the use of peptidases from M. pomifera and to screen for and analyze the released bioactive peptides with ACE-inhibitory activity.

\section{Materials and methods}

\subsection{Chemicals}

Bovine-serum albumin (BSA), captopril, casein, rabbit-lung ACE, 2,4,6-trinitrobenzenesulfonic acid (TNBS), potassium persulfate, Tris(hydroxymethyl)aminomethane (Tris), and zinc chloride were purchased from Sigma Chemical Company (St. Louis, MO, USA); Coomassie Brilliant Blue G-250, acrylamide, bisacrylamide, molecular-weight standards and Tricine from Bio-Rad (Hercules, CA, USA); $\alpha$-cyano-4hydroxycinnamic acid (HCCA) from Bruker Daltonics (Billerica, MA); Abz-PheArgLys(DNP)Pro-OH from Bachem (Bubendorf, Switzerland), trifluoroacetic acid (TFA) from J.T. Backer (Philipsburg, NJ, USA), and Lleucine and trichloroacetic acid from Carlo Erba Reagenti (Rodano, MI, Italy). All other chemicals were obtained from local commercial sources and were of the highest purity available.

\subsection{Preparation and characterization of plant proteolytic extracts}

Ten mature fruits of $M$. pomifera were cut from a single tree (La Plata, Province of Buenos Aires, Argentina) and latex ( $5 \mathrm{~mL}$ ) obtained by making incisions in the fruit and collecting the resulting drops of fluid in $80 \mathrm{~mL}$ of $0.1 \mathrm{M}$ phosphate buffer ( $\mathrm{pH}$ 6.6) containing 5 mM ethylenediaminetetraacetic acid and $5 \mathrm{mM}$ cysteine, in order to avoid phenoloxidase activity and oxidation, respectively. The suspension was centrifuged at $16,000 \mathrm{~g}$ and $4{ }^{\circ} \mathrm{C}$ for $20 \mathrm{~min}$; and the resulting supernatant solution, referred to as pomiferin, was stored in aliquots of $1 \mathrm{~mL}$ at $-20^{\circ} \mathrm{C}$. To remove phenolic compounds, partially purified extracts were prepared by precipitation with one volume of cold ethanol (Bertucci et al., 2015) and termed purified pomiferin extract (PPE). The proteolytic activity of PPE was determined on casein as a substrate and expressed as caseinolytic units per $\mathrm{mL}$ (Ucas/mL), as described by Priolo, López, Arribére, Natalucci, and Caffini (1991). The protein content was determined by the Bradford method (Bradford, 1976), with BSA as the standard. Specific activity was calculated as the ratio between caseinolytic activity and protein concentration (i.e., Ucas/mg).

\subsection{Casein-hydrolysates preparation}

The bovine-casein substrate was prepared by dissolving $12.5 \mathrm{~g}$ casein in $1 \mathrm{~L} 0.1 \mathrm{M}$ Tris- $\mathrm{HCl}$ buffer ( $\mathrm{pH} \mathrm{9.0)}$ ), at $100{ }^{\circ} \mathrm{C}$ for $20 \mathrm{~min}$ with stirring. In order to remove protein aggregates, this hot suspension was then quickly filtered through cellulose filter paper. The hydrolysis of bovine-casein was performed by mixing $10 \mathrm{~mL}$ of PPE (1/5 dilution) with $90 \mathrm{~mL}$ of this casein suspension. Reactions were carried out at $\mathrm{pH} 9.0,45^{\circ} \mathrm{C}$ and stopped at different times $(10,30,60,90$, and $180 \mathrm{~min}$ ) by heat-shock inactivation of the peptidases at $100{ }^{\circ} \mathrm{C}$ for 10 min. Blanks were prepared with casein or PPE at the same dilution as in the reaction mixture through the addition of the appropriate amount of water only. Aliquots of each hydrolysate were filtered by centrifuging through 3-kDa Amicon Ultra-15 filter units (Millipore). The filtered and unfiltered hydrolysates were stored at $-20^{\circ} \mathrm{C}$. In Addition, filtered hydrolysates were lyophilized and stored. The peptide concentration of the hydrolysates was determined by the Lowry method (Lowry, Rosebrough, Farr, \& Randall, 1951).

\subsection{Determination of degree of hydrolysis $(\mathrm{DH})$}

The DH of the casein hydrolysates was determined spectrophotometrically by the TNBS method (Adler-Nissen, 1979), which assay is based on the reaction of the primary amino groups from the hydrolyzed caseins with this reagent. Hydrolysate samples were diluted with $0.213 \mathrm{M} \mathrm{Na}_{2} \mathrm{HPO}_{4}$ containing $1 \mathrm{~g} / 100 \mathrm{~mL}$ sodium dodecyl sulfate (SDS), $\mathrm{pH} 8.2$ to a maximum protein concentration of $1 \mathrm{mg} / \mathrm{mL}$. LLeucine was used as a standard (concentration range: $0-2.25 \mathrm{mM}$ ). Of the samples, $40 \mu \mathrm{L}$ were mixed with $320 \mu \mathrm{L}$ of the same phosphate buffer plus $320 \mu \mathrm{L}$ of a solution of $0.5 \mathrm{~mL} / 100 \mathrm{~mL}$ aqueous TNBS, followed by incubation for $1 \mathrm{~h}$ at $50{ }^{\circ} \mathrm{C}$ in the dark. The reaction was stopped by the addition of $640 \mu \mathrm{L} 0.1 \mathrm{M} \mathrm{HCl}$ at room temperature in the dark and the absorbance measured at $340 \mathrm{~nm} 1 \mathrm{~h}$ later. The DH was expressed as the percent cleavage of peptide bonds with respect to the total number of peptide bonds per protein equivalent (Nielsen, Petersen, \& Dambmann, 2001).

\subsection{Tricine SDS-PAGE}

Samples of the hydrolysates after different digestion times along with the appropriate blanks were analyzed by denaturing electrophoresis in Tricine SDS-PAGE (Corrons et al., 2012). The following molecular markers were employed: phosphorylase B, serum albumin, ovalbumin, carbonic anhydrase, trypsin inhibitor, and lysozyme; corresponding to 97.4, 66.2, 45.0, 31.0, 21.5, and 14.4 kDa, respectively (Bio-Rad; low range). Electrophoresis was carried out in a Mini-Protean III cell (BioRad Laboratories, Watford, UK) with a Tricine SDS-PAGE composed of a stacking gel, a separating gel, and a resolution gel; which combination proved especially suitable for resolving the mixture of peptides produced. The gels were placed in a fixative solution containing $50 \mathrm{~mL}$ of methanol, $10 \mathrm{~mL}$ of acetic acid, and $40 \mathrm{~mL}$ of water, and were then stained with Coomassie Brilliant Blue G-250 for $2 \mathrm{~h}$ at room temperature, followed by an overnight destaining. The electrophoretic profiles were analyzed by densitography through the use of the Image software (Mac OS X, W. Rasband, National Institute of Mental Health, Bethesda, MD, USA).

\subsection{Analysis and partial purification of peptides in hydrolysates by RP-HPLC}

Unfiltered and filtered casein hydrolysates were applied to a Bondclone 10 C-18 column (00H-2117-C0, Phenomenex), operating at room temperature in an ÄKTA-Purifier chromatograph (GE, Uppsala, Sweden) at a flow rate of $2 \mathrm{~mL} / \mathrm{min}$. The column was equilibrated with 4 column volumes (CV) of $0.05 \mathrm{~mL}$ TFA in $100 \mathrm{~mL}$ water (Solution A) before each sample injection. Then, a basic linear gradient from 100\% Solution A to $100 \%$ of $0.025 \mathrm{~mL}$ TFA in $100 \mathrm{~mL}$ acetonitrile (Solution B) was applied in $35 \mathrm{CV}$ (61 min) to obtain a characteristic peptide profile. Alternatively, a step gradient from $100 \%$ Solution A to $30 \%$ Solution $B$ in 29 CV (51 min) was used to separate groups of peptides at a flow rate of $2 \mathrm{~mL} / \mathrm{min}$. The elution was monitored by measurement of absorbance at either 280 or $215 \mathrm{~nm}$.

\subsection{Mass spectrometric analysis}

The molecular weights of peptides in filtered hydrolysates were analyzed by MALDI-TOF MS. One microliter of each sample was mixed with $1 \mu \mathrm{L}$ of crystallization-matrix solution ( $10 \mathrm{mg} / \mathrm{mL}$ HCCA in acetonitrile: water 1:2 with $0.1 \mathrm{~g} / 100 \mathrm{~mL}$ TFA) and then deposited onto a 
ground-steel plate through the use of a standard dried-droplet method. The spectra were collected on an UltrafleXtrem ${ }^{\mathrm{TM}}$ spectrometer (Bruker Daltonics) with FlexControl 3.4 (Bruker Daltonics) data-acquisition software. Mass spectra in the mass range between 600 and $4000 \mathrm{Da}$ were obtained in reflector-mode geometry, with the following settings: reflector, positive mode; ion source $1,25 \mathrm{kV}$; ion source $2,22.55 \mathrm{kV}$; lens, $8 \mathrm{kV}$; reflector $1,26.45 \mathrm{kV}$; reflector $2,13.3 \mathrm{kV}$; a pulsed-ion extraction of $90 \mathrm{~ns}$; and a high-gating ion suppression up to $400 \mathrm{~m} / \mathrm{z}$. The ionization was produced by irradiation with a SmartBeam II laser operating at $1 \mathrm{kHz}$ (30\% attenuator), and the mass calibration performed externally by means of the Peptide Calibration Standard (Bruker Daltonics: angiotensin II, angiotensin I, Substance P, bombesin, ACTH clip 1-17, ACTH clip 18-39, somatostatin 28). The data analysis was performed by the FlexAnalysis 3.4 and BioTools 3.2 software programs (Bruker Daltonics).

In order to determine the possible sequences of the peptides present in the hydrolysates, the principal molecular masses obtained were analyzed by the FindPept software tool (http://web.expasy.org/findpept/) together with the sequences of bovine caseins. With the most promising peptides, MALDI TOF/TOF MS/MS fragmentation analysis was carried out through the use of the following settings: reflector, positive mode; ion source $1,7.5 \mathrm{kV}$; ion source $2,6.75 \mathrm{kV}$; lens, $3.6 \mathrm{kV}$; reflector 1 , $29.5 \mathrm{kV}$; reflector $2,13.9 \mathrm{kV}$; and a pulsed-ion extraction of $50 \mathrm{~ns}$. The identification of the casein peptides was validated by means of the BioTools software (Version 3.2; Bruker Daltonics) by MASCOT (http:// www.matrixscience.com) identification or stochastic interpretation.

\subsection{Determination of ACE-inhibitory activity in hydrolysates}

The analysis of ACE inhibition was carried out on lyophilized samples of filtered hydrolysates dissolved in demineralized water through the use of the fluorogenic substrate Abz-PheArgLys(DNP)Pro-OH (Carmona, Schwager, Juliano, Juliano, \& Sturrock, 2006). ACE activity was determined by incubating in a quartz cuvette $3 \mu \mathrm{L}$ of ACE ( $1 \mathrm{U}$, Sigma) with $2 \mu \mathrm{L}$ of fluorescent-substrate solution in dimethylsulfoxide vehicle (at $0.5 \mathrm{mg} / 100 \mathrm{~mL}$ ) in the presence of $25 \mu \mathrm{L}$ of the hydrolysate sample in a total volume of $3 \mathrm{~mL}$ of $0.1 \mathrm{M}$ Tris- $\mathrm{HCl}$ buffer (pH 7.0) containing $50 \mathrm{mM} \mathrm{NaCl}$ and $10 \mathrm{mM}$ zinc chloride at $37^{\circ} \mathrm{C}$. The reaction was monitored in a spectrofluorometer (model RF-1501, Shimadzu Corporation, Kyoto, Japan) by recording the increase in fluorescence ( $\lambda_{\text {exitation }}, 320 \mathrm{~nm} ; \lambda_{\text {emission }}, 420 \mathrm{~nm}$ ) for $3 \mathrm{~min}$. Positive and negative controls were carried out through the use of a solution of the commercial ACE inhibitor captopril or buffer, respectively. Determinations were done in triplicate and the data expressed as the percentage of ACE inhibition. The $\mathrm{IC}_{50}$ values of certain samples and of captopril were determined by regression analysis of ACE inhibition (\%) vs. concentration $(\mathrm{mg} / \mathrm{mL})$ by means of the Sigmaplot software 10.0 (SPSS Inc., Chicago, IL, USA).

\subsection{Statistical analysis}

All data are reported as the means \pm standard deviation of three replicates. The results of ACE-inhibitory activity were validated by one-way analysis of variance (ANOVA; GraphPad Prism 5, GraphPad Software Inc., La Jolla, CA 92037 USA). Significant differences between the means of the parameters were determined by Tukey's a-posteriori test $(\mathrm{P}<0.05)$.

\section{Results \& discussion}

\subsection{Preparation and characterization of casein hydrolysates}

Latex from the Osage orange containing serine peptidases was used to prepare an extract referred to as pomiferin that exhibited a caseinolytic activity of $26.0 \pm 1.9$ Ucas/mL and had a protein concentration of $3.39 \pm 0.52 \mathrm{mg} / \mathrm{mL}$. The specific activity, calculated as the ratio of those values ( $c f$. Material and methods), was $7.7 \pm 1.3$ Ucas/mg. In order to remove phenolic compounds, the extract initially was partially purified by ethanol precipitation. The enzymatic preparation obtained (PPE) had a specific activity of $7.1 \pm 0.4 \mathrm{Ucas} / \mathrm{mg}$, corresponding to $92 \%$ of the value of the crude extract. Although an increase in specific activity is generally expected when an enzyme preparation is purified, enzymes could be sensitive to traces of residual ethanol that ought to be removed after precipitation (Englard \& Seifter, 1990). In practice, a complete removal is not easy to achieve, and residual ethanol can disrupt interactions that stabilize protein structure thus reducing the enzymatic activity (Mattos \& Ringe, 2001). Trypsin and chymotrypsin, peptidases from animal sources; the subtilisins Carlsberg and NOVO from Bacteria; and proteases from Aspergillus candidus, A. flavus, and A. oryzae of the fungal kingdom are all serine peptidases that have been employed for a long time in numerous industrial processes (Uhlig, 1998). In contrast, plants are a little explored source of serine peptidases. In the present work, we prepared the proteolytic extract from M. pomifera-it containing serine peptidases. This extract constitutes a preparation that is easy to obtain and could be used in specific industrial processes, such as food manufacturing.

Hydrolysates were prepared by mixing $10 \mathrm{~mL}$ PPE (dilution: 1/5) with $90 \mathrm{~mL}$ casein suspension. The protein concentration in these mixtures was $9.5 \pm 0.6 \mathrm{mg} / \mathrm{mL}$. This value indicates that small amounts of casein were lost in the filtration step during the preparation of the substrate.

The casein-hydrolysate bands on Tricine SDS-PAGE exhibited a densitogram indicating a profile of gradual degradation (Fig. 1). After 10 min of hydrolysis, the disappearance of all casein could be observed (Fig.1, record 2). In the zone corresponding to the lower molecular

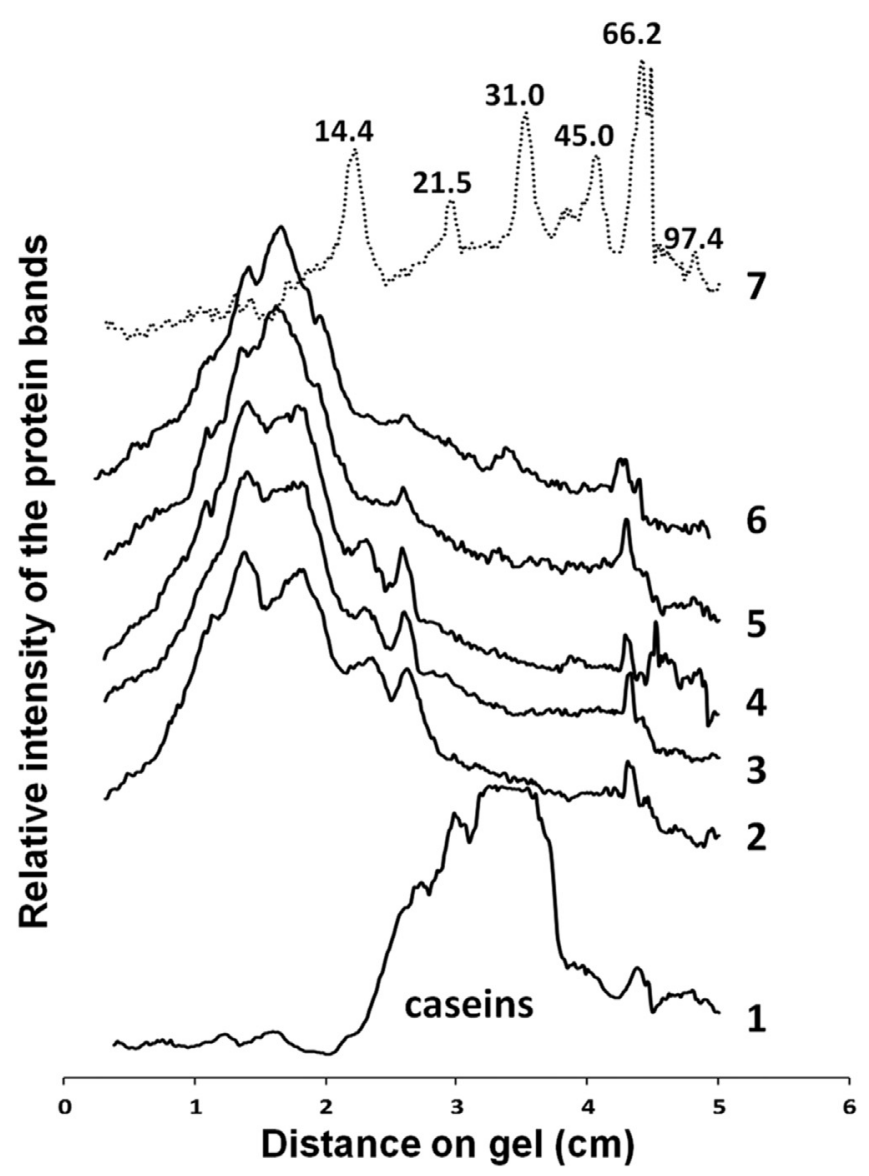

Fig. 1. Densitogram of Tricine SDS-PAGE of casein hydrolysates. Each plot corresponds to the following lanes of casein hydrolysates. 1, casein blank; 2-6, casein hydrolysates after $10,30,60,90$, and 180 min of digestion; 7, molecular-weight markers (low range kit, BioRad). 
weights (i.e., $<20 \mathrm{kDa}$ ), the number of peaks increased with the time of hydrolysis (between10-180 min hydrolysis, records 2-6). In addition, several undefined peaks were detected in the densitogram, which species would be related to the many small peptides released from the caseins.

Fig. 2 shows the corresponding plot of DH vs. hydrolysis time. The digestion was essentially biphasic with an initial rapid linear segment for the first $30 \mathrm{~min}$ (at a rate of $c a .0 .3 \% \cdot \mathrm{min}^{-1}$ ) followed by a second linear portion at a substantially decreased slope (at a rate of $\mathrm{ca} .0 .05 \% \cdot \mathrm{min}^{-1}$ ). The maximum value obtained was $17.1 \pm 0.7 \%$ at 180 min reaction. Since at the time the reaction was stopped no plateau had been reached, longer reaction times would be expected to continue the degradation of proteins and/or peptides.

In a previous investigation (Bertucci et al., 2015), undiluted PPE was used to hydrolyze bovine whey proteins $(5.89 \mathrm{mg} / \mathrm{mL}$ ). Under the same conditions, Tricine SDS-PAGE revealed a degradation of protein bands that only started after 90 min of reaction. This observation verifies that, in general, under the same proteolytic conditions, the hydrolysis of caseins proceeds more easily than the cleavage of whey proteins. Van der Ven et al. considered this difference when they resorted to the use of eleven different proteases to hydrolyze casein and whey proteins. With an aim at obtaining the same DH in all the hydrolysates, those authors used a more dilute enzyme preparation on the caseins than on the whey proteins because they too had observed that caseins were degraded in less time (Van der Ven et al., 2002).

In accordance with the Tricine SDS-PAGE analysis and the DH results, Fig. 3 shows the RP-HPLC chromatograms of the unfiltered hydrolysates. The peptides produced during hydrolysis appeared at lower elution times, being therefore more hydrophilic than the caseins. A similar degradation profile was obtained by Adoui et al. (2013) with casein hydrolysates $(5 \mathrm{~g} / 100 \mathrm{~mL})$ prepared with porcine pepsin, where a $\mathrm{DH}$ of $8.41 \%$ was reached only after $24 \mathrm{~h}$ of hydrolysis.

\subsection{Analysis of peptides produced by hydrolysis}

The hydrolysates were filtered through 3-kDa centrifugal filters. The peptide concentration in the filtered fractions increased with the time of

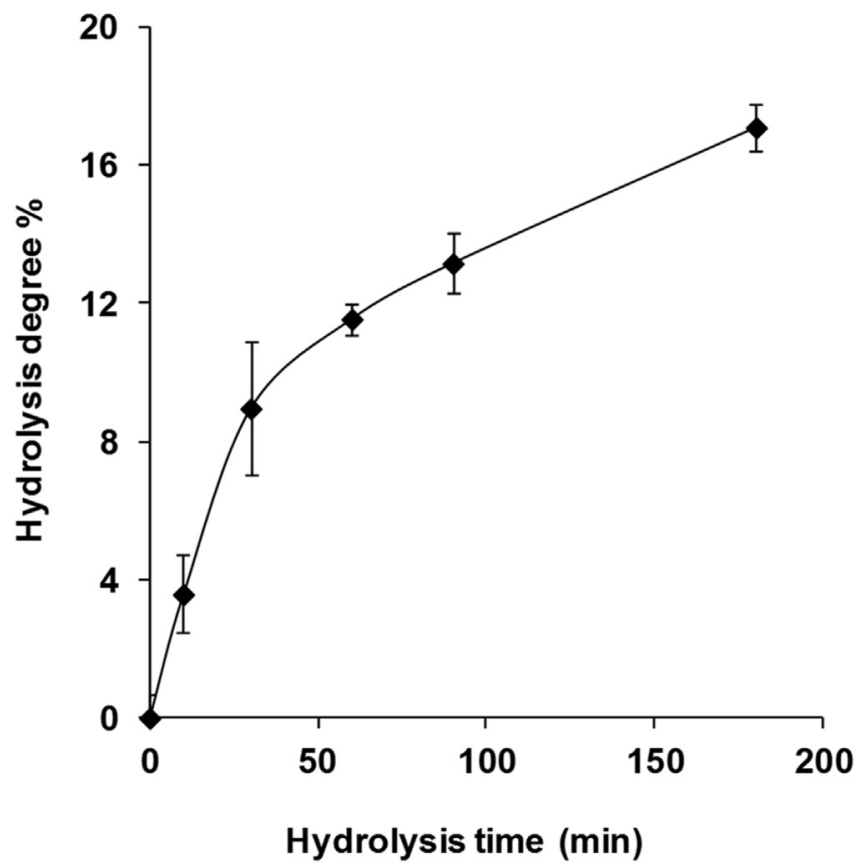

Fig. 2. Degree of hydrolysis with different casein hydrolysates. All determinations were carried out in triplicate. The vertical bars correspond to the standard deviation. In the figure, the percent hydrolysis is plotted on the ordinate as a function of hydrolysis time in min on the abscissa. previous hydrolysis, reaching a value of $1.80 \pm 0.04 \mathrm{mg} / \mathrm{mL}$ after 180 min of hydrolysis. Fig. 4 summarizes analyses by RP-HPLC of the filtered peptides of molecular weight lower than $3 \mathrm{kDa}$ detected as absorbance at $280 \mathrm{~nm}$. After $10 \mathrm{~min}$ of hydrolysis, four major peaks were detected (11 min, $12 \%$ Solution B; $14.5 \mathrm{~min}, 17.5 \%$ Solution B; 21.5 min, 28.1\% Solution B; 24.5 min, 33.8\% Solution B) and continued to be the prominent components up to $180 \mathrm{~min}$ of hydrolysis, though at the last three time points having increased in intensity. Two peaks with much lower intensity in the hydrolysate of $10 \mathrm{~min}$ increased considerably at longer hydrolysis times (15.5 min, 19.5\% Solution B; 22.4 min, 30.8\% Solution B). In the last 90 min of hydrolysis, though the intensity of each main peak increased, the overall profile of the chromatogram remained essentially unchanged. This constant profile of peaks over time could indicate that the proteases from $M$. pomifera possess certain cleavage specificities with peptide bonds.

This pattern was also verified by the mass spectra (MALDI-TOF) of the filtered 60 - and 180-min hydrolysates. Table 1 presents a comparison between the mass values of both hydrolysates, summarized in rows of increasing order of molecular mass. The most intense peak in the hydrolysate of 60 min had a mass value of $1880.963 \mathrm{Da}$, which fragment persisted in the hydrolysate of $180 \mathrm{~min}$ with a similar value (1880.972 Da). Twelve new mass values appeared in the mass spectrum of the 180-min hydrolysate (values indicated in boldface and underlined in Table 1), an observation suggesting that the peptidases had retained their activity at this longer hydrolysis time. Thirty-one different mass fragments were detected in the hydrolysate of $60 \mathrm{~min}$, and only six failed to remain after $180 \mathrm{~min}$ of digestion (masses: 1261.648 , $1508.165,1625.785,1763.530,1996.971$, and $2806.404 \mathrm{Da}$, white on a black background in Table 1). The persistence of certain peptides during the last 90 min of hydrolysis would confirm that their peptide bonds could not be hydrolyzed by these peptidases. A protease's specificity level would depend on the enzyme's biologic function, but that property cannot be predicted. Some of these fragmentations require cleaving peptide bonds between specific amino-acid residues, whereas in most circumstances the entire peptide chain would need to be cut (Costa et al., 2010). Plant proteases participate in numerous physiologic processes such as plant growth and development (Domsalla \& Melzig, 2008), the removal of non-functional proteins, and the regulation of biologic processes that involve a cascade of signals (Sasabe et al., 2000). In particular, certain proteases from latex, such as papain or ficin provide plants with a general defense mechanism against herbivorous insects (Konno et al., 2004). This later function would be expected to not require an elevated level of cut specificity and therefore should happen with latex peptidases from $M$. pomifera. Nevertheless, in biologic processes, unexpected effects can often happen. For example, although in the gastrointestinal digestion of animals nonspecific proteases would presumably be involved because a massive hydrolysis of proteins must occur, this process employs nonspecific proteases such as pepsin along with others of high cleavage specificity such as trypsin (Yu et al., 2012).

\subsection{Determination and partial purification of ACE-inhibitory biopeptides}

In a previous study, when peptidases from $M$. pomifera were used to clot milk, the whey remaining was found to contain ACE-inhibitory activity (Corrons et al., 2012). Assuming that peptides released from milk proteins were responsible for this activity, we now prepared casein hydrolysates under the appropriate enzymatic conditions and evaluated the ACE-inhibitory activity. The data corresponding to that activity in the ultrafiltered hydrolysates exhibited significant differences from the casein blank ( $\mathrm{P}<0.05)$, whereas the PPE blank had no detectable activity. Tukey's test indicated significant differences between different hydrolysis times $(\mathrm{P}<0.05)$. The casein hydrolysate of $180 \mathrm{~min}$ possessed the highest ACE-inhibitory activity, corresponding to an enzyme inhibition of $91.2 \pm 0.3 \%$, under the assay conditions used. The IC $\mathrm{C}_{50}$ of 

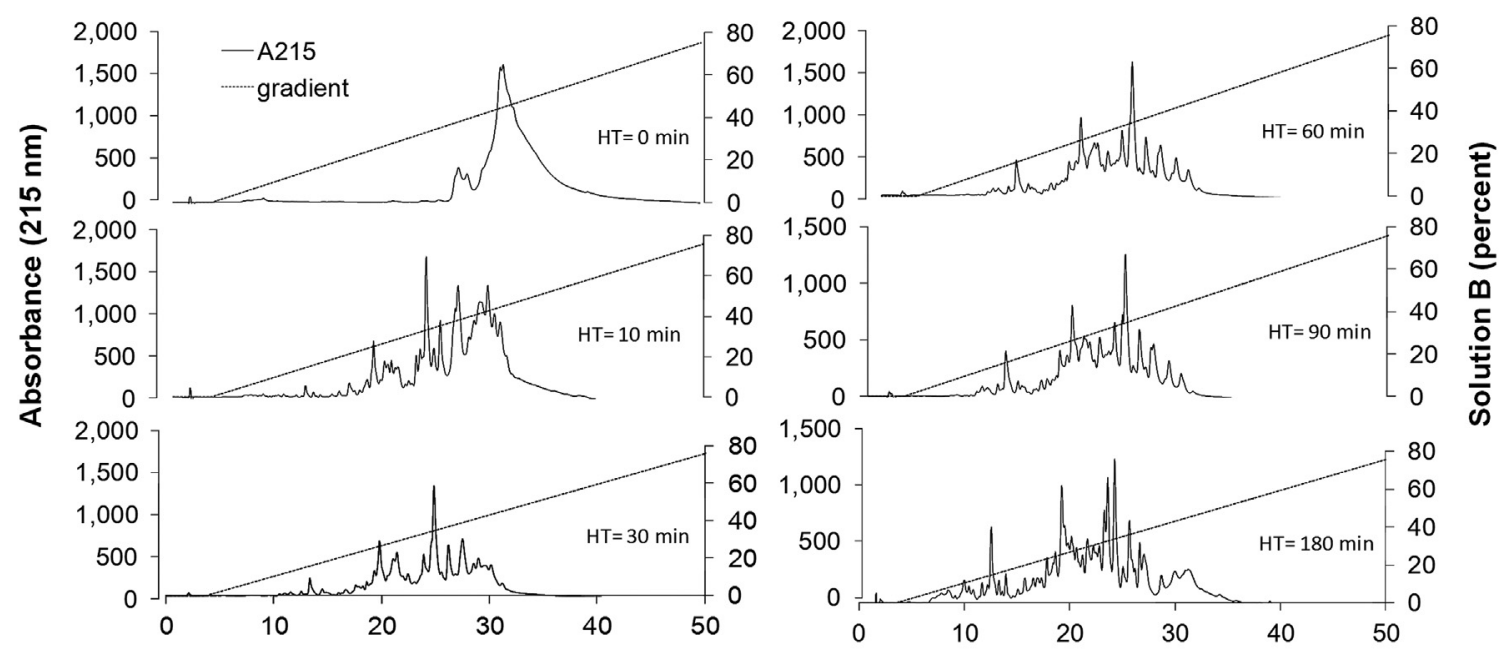

Elution time (min)

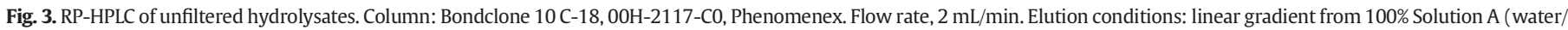

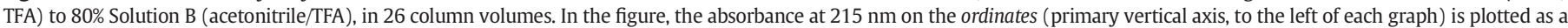
function of the running time in min on the abscissas. As indicated on the right ordinates, the ascending straight lines indicate the percent Solution $\mathrm{B}$ used in the elution profile.

the same hydrolysate after 3-kDa filtration was $1.72 \pm 0.25 \mathrm{mg} / \mathrm{mL}$, a value of similar magnitude to that obtained by Wu, Pan, Zhen, and Cao (2013) for an $\alpha$-casein hydrolysate (i.e., $2.36 \mathrm{mg} / \mathrm{mL}$ ). In the present experiment, captopril was used as a positive control; whose $\mathrm{IC}_{50}$ was $41.9 \pm 5.5 \mathrm{nM}$, a value close to that determined by Villiger, Sala, Suter, and Butterweck (2015).

Peptides from this filtered hydrolysate were partially purified by RP-HPLC through the use of a new acetonitrile gradient (data not shown). Under these conditions, about twenty major peaks were detected at $215 \mathrm{~nm}$ and then collected, lyophilized, and resuspended in distilled water. The ACE-inhibitory assay performed with the chromatographic peaks demonstrated elevated values for the peaks eluted at $44.8 \mathrm{~min}$ (peak $1 ; 15.20 \%$ Solution B) and 78.4 min (peak 2; $24.50 \%$ Solution B), corresponding to $90.3 \%$ and $91.3 \%$ ACEinhibition, respectively.

\subsection{Identification of ACE-inhibitory peptides}

Analysis by MALDI-TOF of the two peaks with the highest ACEinhibitory activity showed two of the masses previously seen in the 180-min hydrolysate: 1881.091 Da in peak 1 and 1109.625 Da in peak 2. Table 2 shows possible amino-acid sequences of peptides corresponding to these masses. These sequences were obtained by comparing those of the $\alpha_{\mathrm{S}^{-}}, \alpha_{\mathrm{S} 2^{-},}, \beta-, \kappa-$ caseins (UniProtKB/Swiss-Prot, protein sequence database; accession numbers: P02662, P02663, P02666, and P02668, respectively) with experimental masses and employing the FindPept software tool for nonspecific cleavage ( $\Delta$ mass tolerance: $\pm 0.1 \mathrm{Da}$ ).

Next, the peptides with molecular masses listed in Table 2 were investigated by MALDI TOF/TOF MS/MS fragmentation analysis. From these data, we could confirm that the peptide sequences were

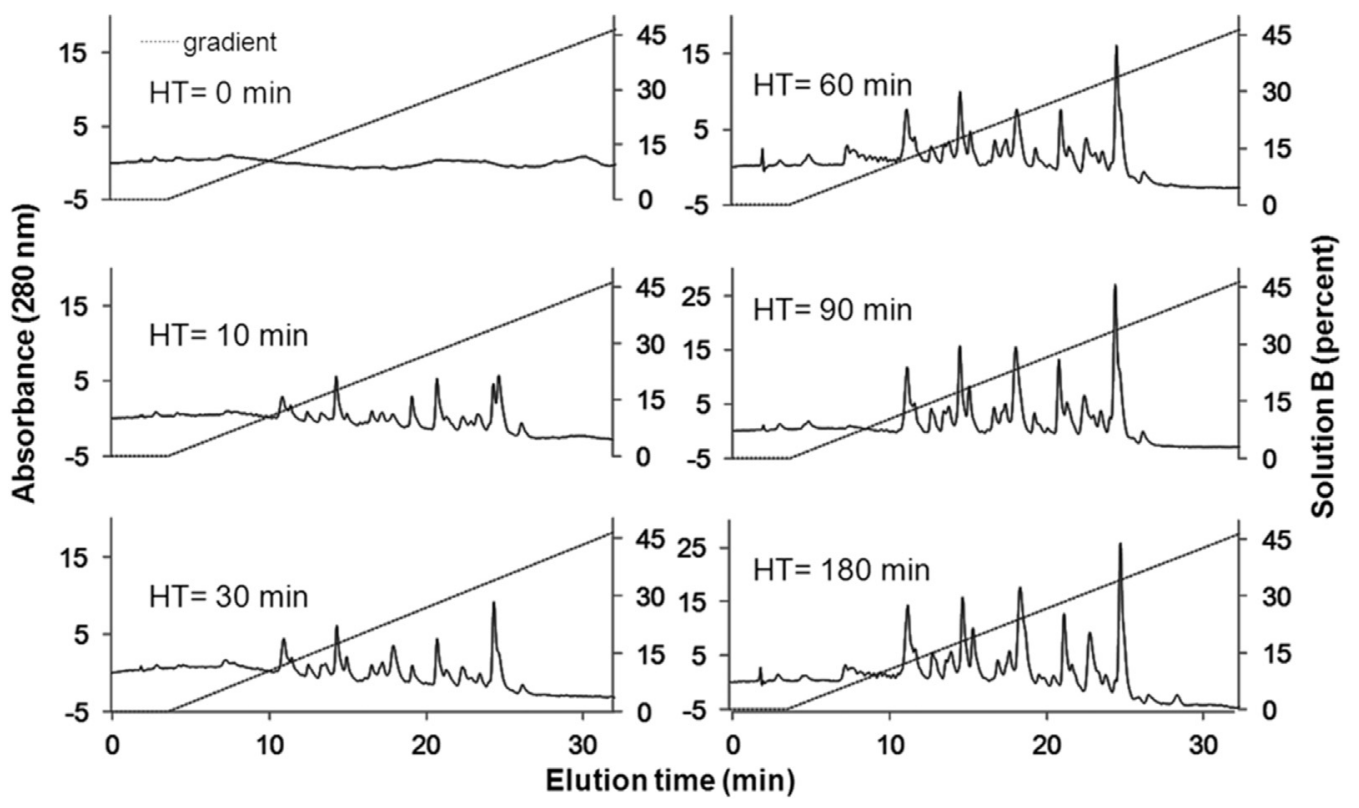

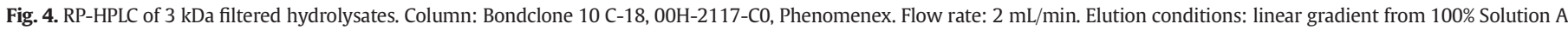

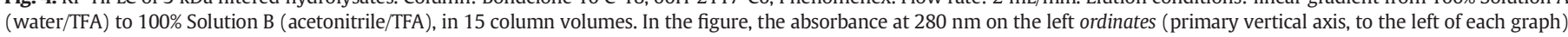

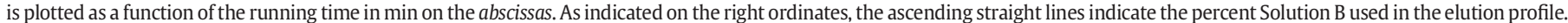


Table 1

Mass values from mass spectrum (MALDI-TOF) of filtered hydrolysates. Comparison between 60- and 180-min hydrolysate masses, presented in rows of increasing order of molecular mass. Each row contains values corresponding to the same peptide in both hydrolysates $(\Delta$ mass $<0.05)$. The underlined boldface values indicate masses appearing at $180 \mathrm{~min}$ of hydrolysis. White values on a black background denote masses from 60 min of hydrolysis that were degraded after 180 min hydrolysis. RN, row number.

\begin{tabular}{|l|l|l|}
\hline RN & $60 \mathrm{~min}$ & $180 \mathrm{~min}$ \\
\hline 1 & & $\underline{\mathbf{9 9 0 . 4 8 0}}$ \\
\hline 2 & & $\underline{\mathbf{1 0 0 1 . 5 5 3}}$ \\
\hline 3 & & $\underline{\mathbf{1 0 0 6 . 4 6 9}}$ \\
\hline 4 & 1109.580 & 1109.594 \\
\hline 5 & 1114.598 & 1114.613 \\
\hline 6 & 1116.549 & 1116.560 \\
\hline 7 & 1134.561 & 1134.574 \\
\hline 8 & 1151.696 & 1151.708 \\
\hline 9 & 1229.627 & 1229.635 \\
\hline 10 & $\mathbf{1 2 6 1 . 6 4 8}$ & \\
\hline 11 & & $\underline{\mathbf{1 2 6 2 . 6 2 5}}$ \\
\hline 12 & 1341.705 & 1341.731 \\
\hline 13 & 1355.687 & 1355.704 \\
\hline 14 & & $\underline{\mathbf{1 3 7 7 . 6 8 2}}$ \\
\hline 15 & 1409.659 & 1409.675 \\
\hline
\end{tabular}

\begin{tabular}{|c|c|c|}
\hline RN & $60 \mathrm{~min}$ & $180 \mathrm{~min}$ \\
\hline 16 & $\mathbf{1 5 0 8 . 1 6 5}$ & \\
\hline 17 & 1545.784 & 1545.791 \\
\hline 18 & 1572.676 & 1572.715 \\
\hline 19 & & $\underline{\mathbf{1 5 9 4 . 6 8 6}}$ \\
\hline 20 & $\mathbf{1 6 2 5 . 7 8 5}$ & \\
\hline 21 & $\mathbf{1 7 6 3 . 5 3 0}$ & \\
\hline 22 & & $\underline{\mathbf{1 7 0 0 . 7 4 8}}$ \\
\hline 23 & 1772.904 & 1772.920 \\
\hline 24 & 1781.885 & 1781.921 \\
\hline 25 & 1800.381 & 1800.427 \\
\hline 26 & 1813.762 & 1813.820 \\
\hline 27 & 1834.942 & 1834.953 \\
\hline 28 & 1862.898 & 1862.955 \\
\hline 29 & 1880.963 & 1880.972 \\
\hline 30 & 1896.963 & 1896.982 \\
\hline
\end{tabular}

\begin{tabular}{|l|l|l|}
\hline RN & $60 \mathrm{~min}$ & $180 \mathrm{~min}$ \\
\hline 31 & & $\underline{\mathbf{1 9 0 2 . 9 4 7}}$ \\
\hline 32 & & $\underline{\mathbf{1 9 1 0 . 8 3 3}}$ \\
\hline 33 & & $\underline{\mathbf{1 9 1 8 . 9 2 1}}$ \\
\hline 34 & 1928.789 & 1928.836 \\
\hline 35 & & $\underline{\mathbf{1 9 5 0 . 8 1 8}}$ \\
\hline 36 & 1994.004 & 1994.050 \\
\hline 37 & $\mathbf{1 9 9 6 . 9 7 1}$ & \\
\hline 38 & 2010.967 & 2010.969 \\
\hline 39 & & $\underline{\mathbf{2 2 0 3 . 0 3 6}}$ \\
\hline 40 & & $\underline{\mathbf{2 3 2 5 . 1 9 7}}$ \\
\hline 41 & 2346.951 & 2346.968 \\
\hline 42 & $\underline{\mathbf{2 8 0 6 . 4 0 4}}$ & \\
\hline 43 & 2882.355 & $\mathbf{2 8 8 2 . 3 8 9}$ \\
\hline 44 & 2995.532 & 2995.474 \\
\hline & & \\
\hline
\end{tabular}

YQEPVLGPVRGPFPIIV (peptide 1: apparent molecular mass 1881.091 Da; Table 2) and RFFVAPFPE (peptide 2: apparent molecular mass 1109.625 Da; Table 2). Fig. 5 shows the 1109.625-Da fragmentation analysis, with the mass values corresponding to different ion series placed above the spectrum. The b-ion series is complete ( 9 mass values), and most masses corresponding to the a- and y-ions were found ( 7 and 5 mass values, respectively). The deduced peptide sequence is written at the top of the figure based on those afore mentioned ions as well as other internal ions not shown in Fig. 5. The sequence of peptide 1 was likewise deduced in the same way (data not shown).

Peptide 1 has been described previously by Ong, Henriksson, and Shah (2007) as an ACE-inhibitor present in Cheddar cheeses made with lactococci and Lactobacillus casei as starters, with that preparation having an $\mathrm{IC}_{50}$ of $101 \mu \mathrm{g} / \mathrm{mL}$. Peptide 2 has not yet been described, but the C-terminal tetrapeptide (PFPE) happens to be the sequence of an ACE-inhibitor peptide described by Meisel (1993) with an IC $_{50}$ of $1000 \mu \mathrm{M}(0.489 \mathrm{mg} / \mathrm{mL})$. Since the ACE biologic function is to recognize and cleave the angiotensin I C-terminal dipeptide, the inhibitory activity of a possible peptide inhibitor is strongly influenced by the C-terminal tripeptide sequence (Jakubczyk \& Baraniak, 2014). Therefore, as the PFPE peptide has ACE-inhibitory activity, we could reasonably assume that Peptide 2 could also be an ACE-inhibitor. This observation would only be valid if the peptide is considered as a competitive inhibitor, but many ACE-inhibitory peptides are not competitive inhibitors of this enzyme. In such a situation, certain typical characteristics of competitive-inhibitor peptide sequences are not relevant since those noncompetitive ones do not interact with the active site. A large amount of information is available on noncompetitive-inhibitor peptides. Accordingly, Ni, Li, Liu, and Hu (2012) performed studies to determine the ACE-inhibitory mechanism of the hexapeptide TPTQQS purified from yeast, which evaluation was based on enzyme-kinetics experiments, isothermal titration calorimetry, and a docking simulation. Since those authors determined that the hexapeptide was a noncompetitive inhibitor, the pattern of amino acids of the $C$ terminal of that ACE-inhibitory peptide did not reflect the typical sequence found in competitive inhibitors of that enzyme.

Numerous studies in spontaneously hypertensive rats and hypertensive human volunteers have demonstrated that several ACE-inhibitory peptides significantly reduced blood pressure, either after intravenous or oral administration. This finding suggests that these peptides could be applied as an initial treatment in mildly hypertensive individuals or as supplemental treatment in frankly hypertensive patients, since those agents exert no acute hypotensive backlash. Low cost and the absence of the undesirable side effects of synthetic ACE inhibitors (e.g., a dry cough, skin rashes and angioedema) make these natural peptides an excellent alternative treatment for hypertension (Erdmann, Cheung, \& Schröder, 2008). Dairy products such as "Calpis" and "Evolus" that contain ACE-inhibitory biopeptides have been commercialized, constituting an alternative in the treatment of the hypertensive population (Ha et al., 2015). In present work, we studied a casein hydrolysate containing in vitro ACE-inhibitory activity. One milliliter of latex from M. pomifera fruits provided the necessary amount of peptidase to hydrolyze at least $800 \mathrm{~mL}$ of $9.5 \mathrm{mg} / \mathrm{mL}$ casein so as to obtain a product containing ACE-inhibitory biopeptides.

\section{Conclusions}

Proteolytic enzymes from M. pomifera are able to release ACEinhibitory peptides from bovine caseins under mild conditions, in a short working time. Casein hydrolysates reach a stable peptide composition at $45^{\circ} \mathrm{C}$ and in $<180 \mathrm{~min}$ of reaction time. Peptides with ACEinhibitory activity were partially purified from such a hydrolysate by chromatographic techniques and two active peptide sequences were identified. This product constitutes a promising ingredient to be included in the design of functional foods. Further studies are required to

Table 2

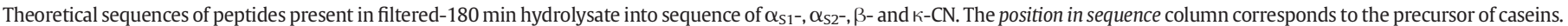
PHOS indicates phosphorylated serines (marked as $\underline{\mathrm{S}}$ in the sequences). The experimental and theoretical mass-value matches were selected with a mass tolerance of \pm 0.1 Da.

\begin{tabular}{|c|c|c|c|c|c|c|}
\hline Experimental mass & Theoretical mass & $\Delta$ mass & $\mathrm{CN}$ & Peptide sequence & Position in sequence & Known modifications \\
\hline \multirow[t]{4}{*}{1881.091} & 1881.042 & -0.048 & \multirow[t]{2}{*}{$\alpha_{\mathrm{S} 1}$} & NLLRFFVAPFPEVFGK & $f(34-49)$ & - \\
\hline & 1881.059 & -0.031 & & SERYLGYLEQLLRLK & $f(103-107)$ & - \\
\hline & 1881.063 & -0.027 & $\beta$ & YQEPVLGPVRGPFPIIV & $f(208-224)$ & - \\
\hline & 1881.034 & -0.056 & $\kappa$ & AAVRSPAQILQWQVLSN & $f(86-102)$ & - \\
\hline \multirow[t]{11}{*}{1109.625} & 1109.567 & -0.058 & \multirow[t]{3}{*}{$\alpha_{\mathrm{S} 1}$} & FVAPFPEVFG & $f(39-48)$ & - \\
\hline & 1109.578 & -0.047 & & RFFVAPFPE & $f(37-45)$ & - \\
\hline & 1109.651 & 0.025 & & LLRFFVAPF & $f(35-43)$ & - \\
\hline & 1109.584 & -0.041 & $\alpha_{\mathrm{S} 2}$ & IISQETYKQ & $f(29-37)$ & - \\
\hline & 1109.526 & -0.098 & \multirow[t]{3}{*}{$\beta$} & VPGEIVESLS & $f(23-32)$ & PHOS \\
\hline & 1109.526 & -0.098 & & VPGEIVES̄LS & $f(23-32)$ & PHOS \\
\hline & 1109.551 & -0.073 & & KYPVEPFTE- & $f(128-13)$ & - \\
\hline & 1109.552 & -0.072 & \multirow[t]{4}{*}{$\kappa$} & AQPTTMARHP & $f(111-120)$ & - \\
\hline & 1109.572 & -0.052 & & PEVIESPPEI & $\mathrm{f}(171-180)$ & - \\
\hline & 1109.581 & -0.043 & & PHLSFMAIPP & $\mathrm{f}(122-131)$ & - \\
\hline & 1109.599 & -0.026 & & YYQQKPVAL & $f(63-71)$ & - \\
\hline
\end{tabular}




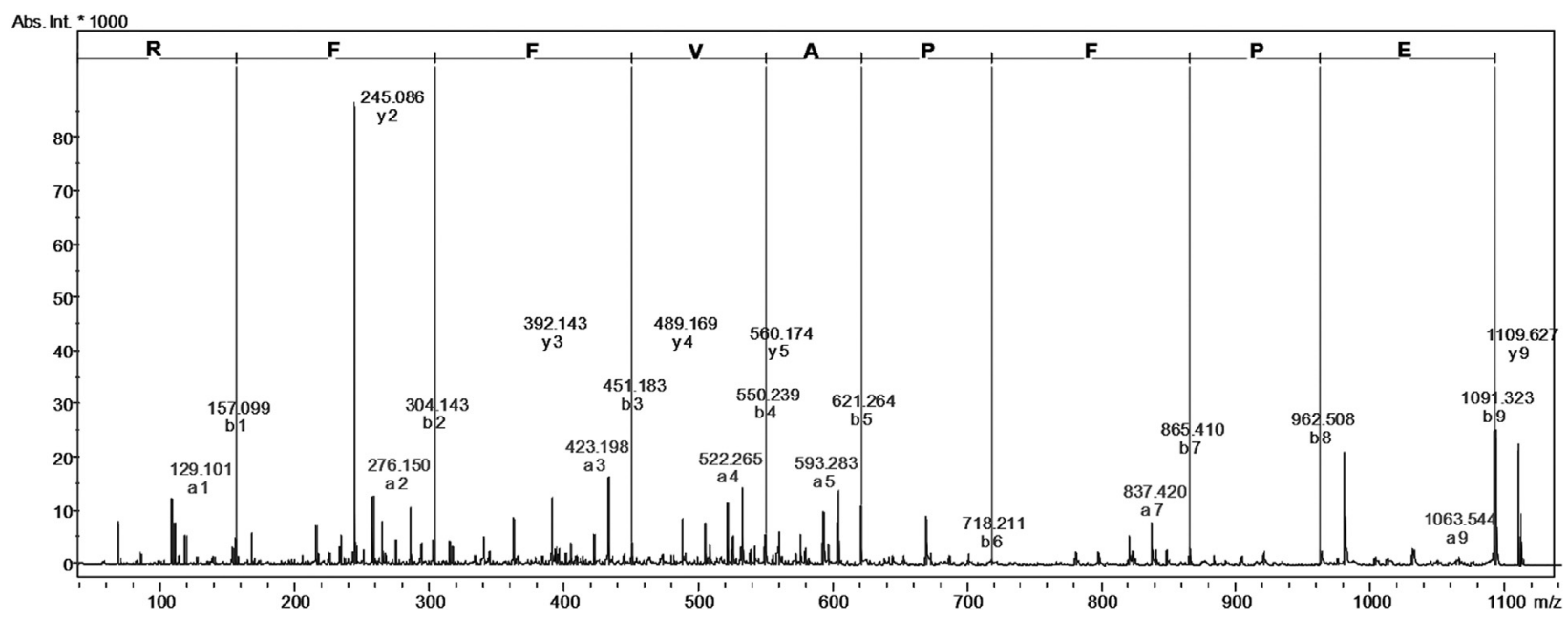

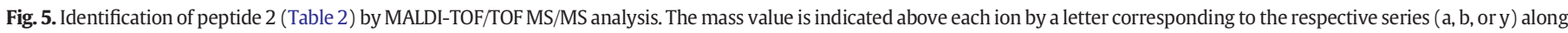

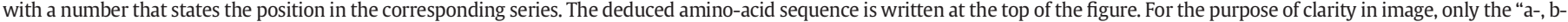
and y-" ions are labelled.

determine the sequences of all the ACE-inhibitory peptides from this hydrolysate and to elucidate their potentials in exerting physiologic effects on the human body. The results of the present work provide a basis for further applications of $M$. pomifera proteases in the food industry for the development of functional foods and nutraceuticals.

\section{Acknowledgements}

The authors are grateful to Eugenia Ghirimoldi from the CICPBA professional scientific editing service for her valuable assistance in preparing the initial version of the manuscript. Donald F. Haggerty, Ph. D., an academic career investigator and native English speaker, edited the final version. The MALDI-TOF MS analyses were carried out in the Proteomics facility of the Universitat Autònoma de Barcelona (UAB), a member of ProteoRed-ISCIII network. This work was supported by grants from ANPCyT (PICT-2013-2531), National University of La Plata, Argentina (Projects X-576 and X-682). M. A. Corrons is a CONICET fellow; C.S. Liggieri is a member of CIC Support Professional Career program; S.A. Trejo and M.A. Bruno are career members of the CONICET.

\section{References}

Adler-Nissen, J. (1979). Determination of the degree of hydrolysis of food protein hydrolysates by trinitrobenzenesulfonic acid. Journal of Agricultural and Food Chemistry, 27, 1256-1262.

Adoui, F., Boughera, F., Chataigne, G., Chihib, N. E., El Hameur, H., Dhulster, P., ... NedjarArroume, N. (2013). A simple method to separate the antimicrobial peptides from complex peptic casein hydrolysate and identification of a novel antibacterial domain within the sequence of bovine $\alpha$ s-casein. International Review of Chemical Engineering, 5, 179-187.

Aleixandre, A., Miguel, M., \& Muguerza, B. (2008). Péptidos antihipertensivos derivados de proteínas de leche y huevo. Nutrición Hospitalaria, 23, 313-318.

Bertucci, J. I., Liggieri, C. S., Colombo, M. L., Vairo Cavalli, S. E., \& Bruno, M. A. (2015). Application of peptidases from Maclura pomifera fruit for the production of active biopeptides from whey protein. Food Science and Technology, 64, 157-163.

Bradford, M. M. (1976). A rapid and sensitive method for the quantitation of microgram quantities of protein utilizing the principle of protein-dye binding. Analytical Biochemistry, 72, 248-254.

Bu, G., Luo, Y., Chen, F., Liu, K., \& Zhu, T. (2013). Milk processing as a tool to reduce cow's milk allergenicity: A mini-review. Dairy Science and Technology, 93, 211-223.

Carmona, A., Schwager, S., Juliano, M., Juliano, L., \& Sturrock, E. (2006). A continuous fluorescence resonance energy transfer angiotensin I-converting enzyme assay. Nature Protocols, 1, 1971-1976.

Clemente, A. (2000). Enzymatic protein hydrolysates in human nutrition. Trends in Food Science and Technology, 11, 254-262.

Corrons, M. A., Bertucci, J. I., Liggieri, C. S., López, L. M. I., \& Bruno, M. A. (2012). Milk clotting activity and production of bioactive peptides from whey using Maclura pomifera proteases. Food Science and Technology, 47, 103-109.
Costa, J. D. O., Fonseca, K. C., Garrote-Filho, M. S., Cunha, C. C., de Freitas, M. V., Silva, H. S., de Oliveira, F. (2010). Structural and functional comparison of proteolytic enzymes from plant latex and snake venoms. Biochimie, 92, 1760-1765.

Domsalla, A., \& Melzig, M. F. (2008). Occurrence and properties of proteases in plant latices. Planta Medica, 74, 699-711.

Englard, S., \& Seifter, S. (1990). Precipitation techniques. In J. N. Abelson, M. I. Simon, \& M P. Deustcher (Eds.), Methods in enzymology. Guide to protein purification (pp. 296-298). USA: Academic Press, Inc.

Erdmann, K., Cheung, B. W., \& Schröder, H. (2008). The possible roles of food-derived bioactive peptides in reducing the risk of cardiovascular disease. The Journal of Nutritional Biochemistry, 19, 643-654.

Gellrich, K., Meyer, H. H. D., \& Wiedemann, S. (2014). Composition of major proteins in cow milk differing in mean protein concentration during the first 155 days of lactation and the influence of season as well as short-term restricted feeding in early and mid-lactation. Czech Journal of Animal Science, 59, 97-106.

Ha, G. E., Chang, O. K., Jo, S. M., Han, G. S., Park, B. Y., Ham, J. S., \& Jeong, S. G. (2015). Identification of antihypertensive peptides derived from low molecular weight casein hydrolysates generated during fermentation by Bifidobacterium longum KACC 91563 Korean Journal for Food Science of Animal Resources, 35, 738-747.

Jakubczyk, A., \& Baraniak, B. (2014). Angiotensin I converting enzyme inhibitory peptides obtained after in vitro hydrolysis of pea (Pisum sativum var. Bajka) globulins. BioMed Research International, 2014, 438459 (8 pages).

Konno, K., Hirayama, C., Nakamura, M., Tateishi, K., Tamura, Y., Hattori, M., \& Kohno, K. (2004). Papain protects papaya trees from herbivorous insects: Role of cysteine proteases in latex. The Plant Journal, 37, 370-378.

Koopman, R., Crombach, N., Gijsen, A. P., Walrand, S., Fauquant, J., Kies, A. K., ... van Loon, L. $\mathrm{J}$. (2009). Ingestion of a protein hydrolysate is accompanied by an accelerated in vivo digestion and absorption rate when compared with its intact protein. The American Journal of Clinical Nutrition, 90, 106-115.

Korhonen, H. (2009). Milk-derived bioactive peptides: From science to applications. Journal of Functional Foods, 1, 177-187.

Korhonen, H., \& Pihlanto, A. (2006). Bioactive peptides: Production and functionality. International Dairy Journal, 16, 945-960.

Lowry, O. H., Rosebrough, N. J., Farr, A. L., \& Randall, R. J. (1951). Protein measurement with the Folin phenol reagent. The Journal of Biological Chemistry, 193, 265-275.

Mattos, C., \& Ringe, D. (2001). Proteins in organic solvents. Current Opinion in Structural Biology, 11, 761-764.

Meisel, H. (1993). Casokinins as bioactive peptides in the primary structure of casein. In K. D. Schwenke, R. Mothes, \& V. C. Weinheim (Eds.), Food proteins, structure and functionality (pp. 67-75). New York: CRC Press.

Ni, H., Li, L., Liu, G., \& Hu, S. Q. (2012). Inhibition mechanism and model of an angiotensin I-converting enzyme (ACE)-inhibitory hexapeptide from yeast (Saccharomyces cerevisiae). PloS One, 7, e37077.

Nielsen, P. M., Petersen, D., \& Dambmann, C. (2001). Improved method for determining food protein degree of hydrolysis. Journal of Food Science, 66, 642-646.

O'Mahony, J. A., \& Fox, P. F. (2014). Milk: An overview. In H. Singh, M. Boland, \& A Thompson (Eds.), Milk proteins: From expression to food (pp. 20-61). Waltham, USA: Academic Press.

Ong, L., Henriksson, A., \& Shah, N. P. (2007). Angiotensin converting enzyme-inhibitory activity in cheddar cheeses made with the addition of probiotic Lactobacillus casei sp. Le Lait, 87, 149-165.

Ortiz, S. M., \& Añón, M. C. (2001). Enzymatic hydrolysis of soy protein isolates. DSC study. Journal of Thermal Analysis and Calorimetry, 66, 489-499.

Pérez Espitia, P., de Fátima Ferreira Soares, N., dos Reis Coimbra, J., de Andrade, N., Souza Cruz, R., Medeiros, A., \& Antonio, E. (2012). Bioactive peptides: Synthesis, properties and applications in the packaging and preservation of food. Comprehensive Reviews in Food Science and Food Safety, 11, 187-204. 
Phelan, M., Aherne, A., FitzGerald, R. J., \& O'Brien, N. M. (2009). Casein-derived bioactive peptides: Biological effects, industrial uses, safety aspects and regulatory status. International Dairy Journal, 19, 643-654

Priolo, N. S., López, L. M. I., Arribére, M. C., Natalucci, C. L., \& Caffini, N. O. (1991). New purified plant proteinases for the food industry. Acta Alimentaria, 20, 189-196.

Sasabe, M., Takeuchi, K., Kamoun, S., Ichinose, Y., Govers, F., Toyoda, K., ... Yamada, T. (2000). Independent pathways leading to apoptotic cell death, oxidative burst and defense gene expression in response to leicitin in tobacco cell suspension culture. European Journal of Biochemistry, 267, 5005-5013.

Silva, S. V., \& Malcata, F. X. (2005). Caseins as source of bioactive peptides. International Dairy Journal, 15, 1-15.

Silva, S. V., Pihlanto, A., \& Malcata, F. X. (2006). Bioactive peptides in ovine and caprine cheeselike systems prepared with proteases from Cynara cardunculus. Journal of Dairy Science, 89, 3336-3344.

Siro, I., Kapolna, E., Kapolna, B., \& Lugasi, A. (2008). Functional food. Product development, marketing and consumer acceptance-A review. Appetite, 51, 456-467.
Soares, R. D., Biasutti, E. A., Capobiango, M., Vieira, C. R., Silva, V. D., Morais, H. A., ... Silvestre, M. P. (2006). Preparation of enzymatic skim milk hydrolysates with low phenylalanine content. Acta Farmaceutica Bonaerense, 25, 325-332.

Uhlig, H. (1998). Description of enzymes. In J. Wiley (Ed.), Industrial enzymes and their applications (pp. 146-179). New York: Wiley-Interscience Publication, USA.

Van der Ven, C., Muresan, S., Gruppen, H., de Bont, D. B., Merck, K. B., \& Voragen, A. G. (2002). FTIR spectra of whey and casein hydrolysates in relation to their functional properties. Journal of Agricultural and Food Chemistry, 50, 6943-6950.

Villiger, A., Sala, F., Suter, A., \& Butterweck, V. (2015). In vitro inhibitory potential of Cynara scolymus, Silybum marianum, Taraxacum officinale, and Peumus boldus on key enzymes relevant to metabolic syndrome. Phytomedicine, 22, 138-144.

Wu, Z., Pan, D., Zhen, X., \& Cao, J. (2013). Angiotensin I-converting enzyme inhibitory peptides derived from bovine casein and identified by MALDI-TOF-MS/MS. Journal of the Science of Food and Agriculture, 93, 1331-1337.

Yu, Z. Chen, L. C. Mandal, M. K. Nonami, H., Erra-Balsells, R. \& Hiraoka, K. (2012). Online electrospray ionization mass spectrometric monitoring of protease-catalyzed reactions in real time. Journal of The American Society for Mass Spectrometry, 23, 728-735. 